\title{
JOYAS DE ARTE RENACENTISTA EN PUEBLA
}

En reciente viaje realizado a Puebla, localicé restos de un monumento que debe contarse entre las manifestaciones más notables de arte renacentista que existen en México. Pude fijar la situación de estas piezas gracias al libro del doctor Hugo lueight Las Calles de Puebla. Sin embargo, él no dice nada acerca de la importancia artística, por lo cual puede ser considerado como un descubrimiento. Se trata de la portada de la antigua Alhóndiga de Puebla. El edificio fué destruído el año de 1899 para construir en su local una ferretería; pero, indudablemente las piedras que formaban la portada llamaron la atención de tal modo a los mismos vándalos que destruían el monumento, que se vieron obligados a conservarlos en la portada del nuevo edificio. Los restos de la portada encuéntranse en la Calle 2 Oriente, en el edificio que es hoy "Cámara de Comercio e Industrias en Pequeño" de Puebla. Constan de dos pares de columnas estriadas, de orden toscano, semejantes a las de la famosa Casa de Montejo en Mérida de Yucatán. Arriba, a los lados del balcón, ornatos renacentistas en forma de $\mathrm{S}$, con fajas vegetajes como de acanto estilizado; en las extremidades, cuatro cabezas: las de arriba con alas, una barbada y otra sin barba, de hombre calvo, ambas de frente; las dos de abajo están de perfil, con barbas y adornos vegetales que les hacen parecer sátiros. En la parte alta de las mismas piedras que contienen estos ornatos, en sus orillas interiores, mensulitas con quterubines. Sobre cada ornato de los estudiados hay medallones circulares, de fajas enrolladas, con figuras de piedra en altorrelieve en su centro, son dos guerreros con armaduras, barbados; el de la izquierda tiene una maza de tronco de árbol y el otro una pequeña espada. Estos altos relieves son muy semejantes a los que se ven a los lados de la puterta en la casa llamada "De las Cabezas", en Puebla, frente a la portada Jateral de la iglesia de San Agustín.

En la parte alta, al centro, se ve el escudo de Puebla, pero puede observarse que ha sido tallado en el escudo de un particular, pues se conservan del anterior los siguientes elementos: un bello yelmo viendo hacia la izquierda, con un águila posada en él y restos del lambrequin de adornos 
vegetales y con cascabeles, como en el escudo de la Casa de Montejo. E, escudo, propiamente dicho, conserva su perímetro y en él se ha tallado un relieve de la catedral con sus dos torres, en vez del castillo tradicional del escudo de Puebla, y, destruyendo parte del lambrequín, se han incrustado dos ménsulas sobre las cuales se colocaron dos ángeles de argamasa que se están destruyenda. Del yelmo salen bellas plumas que se reparten armoniosamente en una especie de nicho. La inscripción del escudo de Puebla se encuentra, en la parte alta, en el borde y, en la parte baja, dentro del mismo escudo.

Tales son los restos de esta obra'de arte que puede ser reconstruida en su estado primitivo, si se toma en cuetita la fơtografia que publicó Leight en su libro tal como se encontraba en sa estado original:

M. T. 